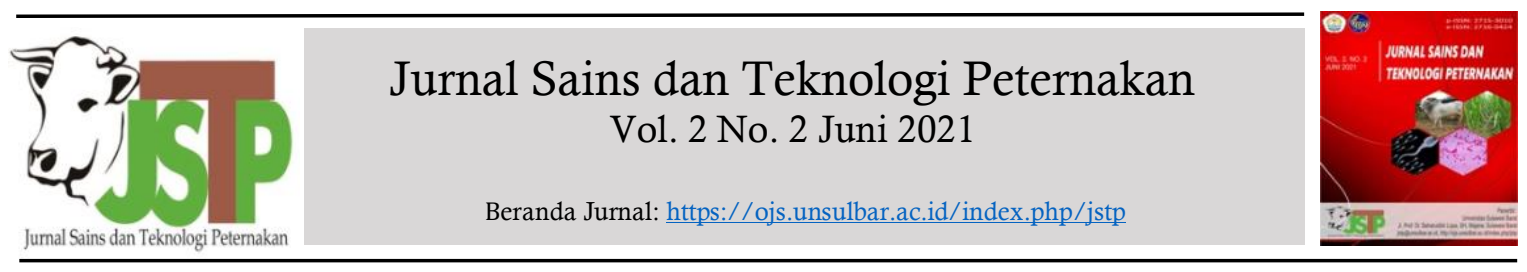

\title{
Karakteristik dan Kualitas Semen Sapi Sumba Ongole dalam Pengencer BTS yang Dimodifikasi dengan Susu Kedelai
}

(Characteristic and Quality of Sumba Ongole Bull Semen in BTS Dilution Modified with Soybean Milk)

Alphonsius Umbu Jara Lodu ${ }^{1 *}$, Alexander Kaka ${ }^{1}$, Iven Patu Sirappa ${ }^{1}$

${ }^{1}$ Program Studi Peternakan, Fakultas Sains dan Teknologi, Universitas Kristen Wira Wacana Sumba, J1. R Suprapto No. 35, Waingapu, Prailiu, Sumba Timur, Nusa Tenggara Timur 87113.

A R T I C L E IN F O

Received: 29 April 2021

Accepted: 14 Juni 2021

*Corresponding author alphonsjalo@gmail.com

Keywords:

Bestvile thawing solution

Soybean milk

Sumba Ongole bulls
Kata Kunci:

Beltsvile thawing solution, Sapi Sumba Ongole Susu kedelai

\section{A B S T R A C T}

This study aimed to find out the quality of fresh semen from Sumba Ongole (SO) bulls which was diluted with Bestvile Thawing Solution (BTS) diluent modified with soybean milk (SKD). The study used a completely randomized design consisting of four treatments and 5 replications, P0 (100\% BTS), P1 (95\% BTS + $5 \%$ SM), P2 (90 \% BTS $+10 \% \mathrm{SM})$, and P3 (85\% BTS + $15 \% \mathrm{SM})$. The parameters observed were the colour, smell, consistency, $\mathrm{pH}$, volume, motility, viability and abnormalities of spermatozoa. The results showed that the characteristics were in the normal, creamy white semen colour, semen volume 3,6 ml, medium consistency, $\mathrm{pH}$ 6,3, typical SO bulls smell, sperm motility $85 \%$, mass activity +++ , sperm concentration 1276 million/ml, live sperm 90,05 \% and sperm abnormalities $6,15 \%$ and quality there was no significant difference between the four treatments. The spermatozoa motility and viability in each treatment was able to which achieved on day 1 . The characteristics of the spermatozoa of SO bulls were in the normal category. Meanwhile, BTS diluent with the addition of SKD was unable to maintain sperm quality. A B S T R A K
Penelitian ini bertujuan untuk mengetahui kualitas semen segar sapi
Sumba Ongole (SO) yang diencerkan dengan pengencer Beltsvile
Thawing Solution (BTS) yang dimodifikasi dengan susu kedelai (SKD).
Materi yang digunakan berupa semen segar pejantan sapi SO.
Penelitian mengunakan Rancangan Acak Lengkap yang terdiri dari
empat perlakuan dan 5 ulangan, P0 (100\% BTS,) P1 (95\% BTS + 5\%
SKD), P2 ( $90 \%$ BTS + $10 \%$ SKD), dan P3 (85\% BTS + $15 \%$ SKD).
Parameter yang diamati adalah warna, bau, konsistensi, pH, volume,
motilitas, viabilitas dan abnormalitas spermatozoa. Hasil penelitian
menunjukan bahwa karakteristik semen normal, warna semen putih
krem, volume semen 3,6 ml, konsistensi sedang, pH 6,3 , bau khas sapi
SO, motilitas $85 \%$ gerakan massa,+++ konsentrasi 1276 juta/ml,
viabilitas $90,05 \%$ dan abnormal $6,15 \%$ dan kualitas spermatozoa
menunjukkan tidak terdapat perbedaan yang signifikan antara empat
perlakuan. Motilitas dan viabilitas spermatozoa pada masing-masing
perlakuan mampu bertahan hingga hari ke-1. Karakteristik
spermatozoa sapi SO berkategori normal. Pengencer BTS dengan
penambahan SKD tidak mampu mempertahankan kualitas
spermatozoa. 


\section{Pendahuluan}

Sapi merupakan satu diantara beberapa ternak ruminasia besar yang potensial sebagai ternak sumberdaya penghasil daging yang dimanfaatkan untuk pemenuhan dan peningkatan gizi masyarakat. Fuadi \& Sugiarto (2019) menyatakan bahwa daging sapi adalah salah satu sumber nutrisi hewani yang harus dipersiapkan untuk pemenuhan gizi masyarakat. Ternak sapi Sumba Ongole (SO) merupakan salah satu sumber pangan hewani yang telah berkembang di Sumba dan ditetapkan sebagai ternak sumber daya genetik sapi lokal Indonesia yang dikembangkan di wilayah Provinsi Nusa Tenggara Timur (NTT) yakni di Pulau Sumba sebagai wilayah sebaran asli geografisnya (Menteri Pertanian Republik Indonesia, 2014). Selain itu, sapi SO berperan penting dalam pemenuhan kehidupan ekonomi, sosial dan budaya masyarakat Sumba.

Berdasarkan data BPS Kabupaten Sumba Timur (2019) dilaporkan bahwa populasi ternak sapi dalam kurun waktu 4 tahun mengalami fluktuasi yang tidak stabil dari tahun 2014 - 2018 yakni pada tahun 2014 sampai tahun 2016 terjadi penurunan pertumbuhan sebesar 27,81 \% per tahun. Pada tahun 2017 terjadi peningkatan pertumbuhan yakni 35,23\%. Namun pada 2018 pertumbuhan sapi hanya sebesar $4,75 \%$. Kondisi tersebut apabila tidak ditangani dikhawatirkan dapat mengakibatkan terjadinya pengurasan populasi, mengancam keberlanjutan Sumber daya genetik lokal.

Salah satu upaya untuk meningkatan populasi ternak sapi SO dapat dilakukan melalui inseminasi buatan (IB) yang bertujuan untuk peningkatan produktivitas dan perbaikan mutu genetik ternak. Faktor-faktor penting yang dapat menjadi penentu keberhasilan pelaksanaan IB dipengaruhi oleh kualitas semen yang baik, keterampilan/keahlian dari inseminator, upaya mempertahankan kualitas semen setelah ejakulasi maupun selama penyimpanan pada suhu rendah. Oleh karena itu, perlu dilakukan preservasi semen untuk mempertahankannya dalam kurun waktu lebih lama (MataHine, Burhanuddin, \& Marawali, 2014). Preservasi semen membutuhkan bahan pengencer yang dapat memenuhi kebutuhan spermatozoa selama proses penyimpanan. Menurut Ismaya (2014), unsur fisik dan kimiawi yang digunakan dalam bahan pengencer harus sesuai dengan kebutuhan spermatozoa yang tidak bersifat toksik serta aman bagi organ reproduksi ternak betina. Begitu pula Kusumawati \& Leondro (2014) menyatakan bahwa penggunaan bahan pengencer semen yang baik harus bisa memenuhi nutrisi spermatozoa selama masa penyimpanan, pergerakan progresif dari spermatozoa, aman dan tidak bersifat racun, serta mampu menjadi penyanggah dan dapat melindungi sel spermatozoa dari cold shock.

Pengencer Beltsville Thawing Solutions (BTS) berfungsi sebagai sumber energi dan buffer karena mengandung glukosa dan EDTA (Dapawole, 2014). Sedangkan menurut Bebas, Buyona, \& Budiasa (2016), pengencer BTS mampu mengikat aktivitas kalsium yang berpotensi terjadinya kapasitasi dini karena terdapat EDTA, kemudian potassium yang berfungsi menjaga transportasi ion metabolisme dan glukosa sebagai sumber energi. Meskipun demikian, pengencer BTS tidak mengandung lesitin sehingga perlu ditambahkan bahan yang bersumber lesitin. Susu kedelai merupakan salah satu sumber lesitin dan telah terbukti mampu mempertahankan kualitas semen. Rahayu, Pramana, \& Ciptadi (2014) menyatakan bahwa kedelai merupakan bahan pengencer mengandung lesitin untuk melindungi spermatozoa dari kecaman dingin (cold shock). Lesitin bekerja dalam semen dengan cara pengencer berikatan dengan membran plasma untuk menyelimuti membran plasma sehingga kestabilan membran semen dapat terjaga sehingga dengan demikian kualitas spermatozoa dapat dipertahankan (Purwoistri, Susilawati, \& Rahayu, 2013). Kandungan lesitin dalam kedelai terbukti lebih tinggi dibandingkan dengan lesitin dalam kuning telur. Selain itu, kedelai terbukti dapat menekan tingkat kontaminasi terhadap bakteri dibandingkan kuning telur (El-Keraby, Osman, Ganah, \& El-Siefy, 2010). Penelitian ini bertujuan untuk mengetahui karakteristik dan kualitas spermatozoa sapi SO dalam pengencer BTS yang dimodifikasi dengan susu kedelai (SKD).

\section{Materi dan Metode}

\subsection{Tempat dan Waktu Penelitian}

Penelitian ini dilaksanakan di dua tempat yaitu tempat penampungan semen di Kambaniru, Kecamatan Kambera, Kabupaten Sumba Timur dan pengambilan data hasil evaluasi dilakukan di Laboratorium Terpadu Universitas Kristen Wira Wacana, Sumba, Kabupaten Sumba Timur dengan jarak lokasi penampungan semen sampai ke Laboratorium $\pm 2 \mathrm{Km}$ yang ditempuh dalam waktu \pm 15 menit. Waktu penelitian dilaksanakan pada bulan November - Desember 2020. 


\subsection{Materi Penelitian}

Materi penelitian yang digunakan adalah semen berasal dari 1 ekor sapi jantan Sapi SO umur $\pm 2,5$ tahun dengan kondisi tubuh yang sehat dan bereproduksi normal dan terlatih. Semen yang dihasilkan ditampung menggunakan vagina buatan yang dilakukan selama dua kali dalam seminggu.

\subsection{Rancangan Perlakuan}

Penelitian ini menggunakan Rancangan Acak Lengkap dengan 4 perlakuan dan 5 ulangan, sehingga diperoleh 20 unit percobaan. Adapun keempat perlakuan yang dicobakan yaitu $\mathrm{P0}=$ Pengencer BTS $100 \%, \mathrm{P} 1=$ Pengencer BTS $95 \%+$ SKD $5 \%$, P2 = Pengencer BTS $90 \%+$ SKD $10 \%$, P3 = Pengencer BTS $85 \%+$ SKD $15 \%$.

\subsection{Variabel Penelitian}

Parameter yang diamati dalam penelitian ini dilakukan dengan dua indikator yakni karakteristik semen segar yang meliputi warna semen, bau, konsistensi, $\mathrm{pH}$, volume, motilitas, viabilitas, dan abnormalitas, serta kualitas semen yang meliputi motilitas dan viabilitas terhadap pengaruh perlakuan.

\subsection{Prosedur Penelitian}

\section{Karalteristik Semen Sapi SO}

Pengamatan karakteristik semen sapi SO dilakukan melalui beberapa tahapan. Mula-mula dilakukan penampungan semen sapi dengan menggunakan vagina buatan dengan suhu 42$45^{\circ} \mathrm{C}$ dan sebagai pemancing menggunakan sapi betina dewasa untuk meningkatkan libido ternak jantan. Setelah didapatkan semen segar, maka dilakukan evaluasi makroskopis yang meliputi: volume, warna, bau, konsistensi dan $\mathrm{pH}$. Volume dan warna semen dapat langsung diketahui setelah penampungan karena tabung penampung mempunyai skala ukur dan berwarna transparan sehingga volume dan warna semen dapat langsung diamati. Aroma/bau semen diukur dengan cara semen yang sudah ditampung didekatkan ke hidung untuk dibaui. Bau semen normal yaitu amis khas sperma ternak sapi. Konsistensi semen diketahui dengan memiringkan secara perlahan semen di dalam tabung penampung dan mengembalikan ke posisi semula sehingga diketahui kecepatan cairan kembali ke posisi semula. Derajat keasaman $(\mathrm{pH})$ diukur dengan meneteskan semen pada kertas indikator $\mathrm{pH}$ (skala 0-14), sehingga perubahan warna pada kertas dapat dibandingkan dengan warna standar.

Evaluasi mikroskopis dilakukan dengan menguji gerakan massa, motilitas, konsentrasi, presentase viabilitas semen, dan abnormalitas spermatozoa. Evaluasi gerakan massa dilakukan dengan meneteskan satu tetes semen di atas gelas objek tanpa menggunakan cover glass dan diamati dengan pembesaran mikroskop $10 \times 10$. Gerakan massa digolongkan sangat baik $(+++)$ jika terlihat adanya gelombang besar, banyak, gelap, tebal dan aktif seperti gumpalan awan hitam dekat waktu hujan yang bergerak secara cepat berpindah-pindah tempat, baik $(++)$ bila terapat gelombang-gelombang kecil tipis, jarang, kurang jelas dan bergerak lamban, kurang baik (+) jika tidak terlihat gelombang melainkan gerakan-gerakan individual aktif progresif dan buruk. Pengamatan motilitas dilakukan dengan cara meneteskan semen dan $\mathrm{NaCl}$ fisiologis diteteskan pada permukaan gelas objek (1:3) di atas gelas objek yang ditutup dengan cover glass, kemudian diamati mengunakan mikroskop dengan pembesaran $10 \times 40$. Konsentrasi spermatozoa dihitung menggunakan neubauer chamber dengan cara mengisap semen sampai tanda 0,5 menggunakan pipet erythrocyt, kemudian eosin dihisap sampai tanda 1,01 lalu dihomogenkan dengan hati-hati selama 2-3 menit dengan membentuk angka delapan. Perhitungan spermatozoa dilakukan pada lima kotak besar yang terletak diagonal. Pengamatan dilakukan dengan pengamatan mikroskopik pembesaran $10 \times 40$. Persentase viabilitas dilakukan dengan pewarnaan diferensial menggunakan eosin $2 \%$ dengan perbandingan semen dan eosin (1:3). Kemudian dihomogenkan diatas gelas objek dan dibuat preparat ulas tipis pada objek dan dikeringkan. Pengamatan dilakukan dengan pengamatan mikroskopik pembesaran $10 \times 40$. Spermatozoa hidup ditandai dengan bagian kepala berwarna putih, sedangkan yang mati dengan warna kepala merah. Abnormalitas. Pengamatan abnormalitas diamati bersamaan dengan pengamatan viabilitas. Tampilan spermatozoa dievaluasi menggunakan pewarna diferensial eosin $2 \%$. Spermatozoa dinilai secara morfologi normal atau tidak, pada bagian kepala, leher dan ekor. Spermatozoa yang diamati minimal 200 sel atau 10 lapang pandang menggunakan mikroskop perbesaran $10 \times 40$.

\section{Kualitas Semen Sapi SO}

Pengamatan kualitas sapi SO dilakukan dengan cara: mula-mula sperma diecerkan dengan standar minimal semen yaitu di atas 
$70 \%$, kemudian disimpan pada lemari pendingin dengan suhu $3-5{ }^{\circ} \mathrm{C}$. Setelah dilakukan pengenceran, selanjutnya dilakukan evaluasi secara mikroskopis yang meliputi motilitas dan viabilitas semen. Pengamatan motilitas dilakukan dengan cara meneteskan semen dan $\mathrm{NaCl}$ fisiologis diteteskan pada permukaan gelas objek (1:3) di atas gelas objek yang ditutup dengan cover glass, kemudian diamati mengunakan mikroskop dengan pembesaran 10 $\times 40$. Pengukuran persentase viabilitas dilakukan dengan pewarnaan diferensial menggunakan eosin $2 \%$ dengan perbandingan semen dan eosin (1:3). Kemudian dihomogenkan diatas gelas objek dan dibuat preparat ulas tipis pada objek dan dikeringkan. Pengamatan dilakukan dengan mikroskop pembesaran $10 \times 40$. Spermatozoa hidup ditandai dengan bagian kepala berwarna putih, sedangkan yang mati dengan warna kepala merah. Proses evaluasi dilakukan setiap 24 jam penyimpanan sampai motilitas dan viabilitas mencapai $40 \%$.

\subsection{Analisis Data}

Data evaluasi semen segar dianalisis menggunakan analisis deskriptif statistik untuk mencari nilai rataan dan nilai standar deviasi sedangkan data motilitas dan viabilitas hasil pengenceran dianalisis menggunakan analisis of varience (ANOVA). Jika terjadi perbedaan antar perlakuan dilanjutkan dengan uji Beda Nyata Terkecil (BNT) (Steel \& Torrie, 1991). Data diolah dengan program SPSS versi 23,0.

\section{Hasil dan Pembahasan}

Karakteristik semen segar sapi SO hasil pengamatan secara makroskopis dan makroskopis dapat dilihat pada Tabel 1. Uji secara makroskopis meliputi warna, volume, kekentalan, $\mathrm{pH}$ dan bau sedangkan uji secara mikroskopis meliputi motilitas, gerakan massa, konsentrasi, viabilitas dan abnormalitas. Rataan Karakteristik semen segar sapi SO dapat dilihat pada Tabel 1.

Berdasarkan Tabel 1, warna semen yang diperoleh dalam penelitian ini adalah putih krem dan dinyatakan warna dalam kategori normal. Adhyatma, Isnaini, \& Nuryadi (2013) menyatakan bahwa warna semen sapi yang normal berwarna putih susu atau krem keputihan. Hal ini juga disampaikan Susilawati (2013) yang menyatakan bahwa umumnya warna semen sapi berwarna putih kekuningan atau seperti putih susu karena terdapat kandungan riboflavin yang mempunyai sifat autosomal resesif. Sulistyowati, Faris, Yekti,
Wahjuningsih, \& Susilawati (2018) dalam penelitiannya juga menyatakan bahwa warna semen segar sapi berwarna putih kekuningan. Hal ini juga dilaporkan Ina \& Kaka (2020) dalam penelitiannya memperoleh warna semen sapi berwarna putih krem.

Tabel 1. Rataan karakteristik semen segar sapi $\mathrm{SO}$

\begin{tabular}{lll}
\hline $\begin{array}{l}\text { Karakteristik } \\
\text { Semen }\end{array}$ & Variabel & Mean \pm SD \\
\hline Makroskopis & Warna & Putih krem \\
& Volume (ml) & $3.6 \pm 1.38$ \\
& Konsistensi & Sedang \\
& pH & $6.3 \pm 0.07$ \\
& Aroma/Bau & Khas \\
Mikroskopis & Motilitas (\%) & $85.00 \pm 3.53$ \\
& Gerakan Massa & +++ \\
& Konsentrasi (10 & $1276.00 \pm 487.37$ \\
& /ml) & \\
& Viabilitas (\%) & $90.05 \pm 10.98$ \\
& Abnormalitas (\%) & $6.15 \pm 1.81$ \\
\hline Sumber: Data primer yang telah diolah
\end{tabular}

Volume semen sapi yang didapatkan dalam penelitian ini sebesar $1,5-5 \mathrm{ml}$ dengan nilai rataan volume semen sebesar 3,6 $\pm 1,38 \mathrm{ml}$. Volume semen segar yang didapatkan memiliki hasil yang lebih rendah dibandingkan dengan hasil yang diperoleh Prasetyo (2019) pada penelitiannya bahwa volume semen sapi umur 1,5 dan 2 tahun memiliki rataan volume semen segar masing-masing 4,55 $\pm 1,00 \mathrm{ml}$ dan 5,41 \pm $0,96 \mathrm{ml}$ juga lebih rendah dari penelitian Sholikah, Isnaini, Puspita Anugra Yekti, \& Susilawati (2016) yang melaporkan bahwa volume semen sapi yang didapatkan sebesar $5,9 \pm 1,9 \mathrm{ml}$. Sedangkan volume semen segar yang didapatkan lebih besar dibandingkan dengan hasil yang diperoleh Sulistyowati et al. (2018) dalam penelitiannya melaporakan bahwa rataan

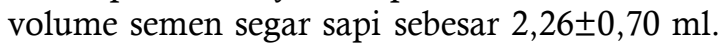
Menurut Direktorat Budidaya Ternak Ruminansia (2010), volume semen sapi memiliki kisaran 5-10 ml, dan Hartanti, Setiati, \& Sutopo (2012) volume semen sapi dalam kategori normal berkisar 3,2-7,3 $\mathrm{ml}$ dan (Arifiantini, 2012) rataan volume semen sapi adalah 4-8 $\mathrm{ml}$. Adanya perbedaan volume semen pada ternak sapi diakibatkan oleh perbedaan bobot badan, umur sapi jantan yang digunakan maupun libido pejantan saat penampungan. Hal ini sesuai dengan pernyataan Saputra, Ihsan, \& Isnaini (2017) bahwa keberangaman volume semen yang dihasilkan dipengaruhi oleh kondisi bobot badan sapi, umur yang berbeda maupun libido pejantan saat ditampung. Selanjutnya Feradis (2010) menyatakan bahwa ukuran testis pada ternak sapi yang berbeda menyebabkan perbedaan 
volume semen segar. Kesuburan pejantan memiliki kaitan terhadap ukuran testis sehingga produksi semen juga ikut berpengaruh karena testis merupakan organ reproduksi primer pejantan, dengan demikian bobot badan berpengaruh pada volume semen baik secara kualitas maupun kuantitasnya (Arifiantini, Nally, Susnawati, \& Rochmiati, 2014).

Konsistensi semen sapi yang diperoleh dalam penelitian ini adalah sedang. Hasil penelitian ini sesuai dengan hasil penelitian Ina \& Kaka (2020) bahwa semen sapi memiliki konsistensi sedang. Hal serupa juga dilaporkan Prasetyo (2019) bahwa sapi umur 1,5 tahun memiliki konsistensi sedang dan sapi umur 2 tahun memiliki konsistensi kental. Adanya perbedaan konsistensi semen pada ternak sapi di duga diakibatkan oleh kualitas pakan yang diberikan dan tingkat rangsangan saat penanpungan semen. Hal ini sesuai dengan penyataan Dewi, Ondho, \& Kurnianto (2012) bahwa faktor yang menyebabkan rendahnya konsistensi dipengaruhi oleh kualitas pakan yang diberikan, pemberian pakan haruslah seimbang antara hijauan dan konsentrat dan leguminosa. Selain itu tingkat rangsangan juga mempengaruhi konsistensi semen. Konsistensi semen memiliki kaitan erat dengan tingkat konsentrasi spermatozoa dimana konsitensi sedang jika terdapat 1.000.106-1.500.106 spermatozoa/ml semen (Susilawati, 2013) dan Khairi (2017) menyatakan perkembangan seksual, kedewasaan, kualitas pakan, kesehatan alat reproduksi, ukuran testis, umur dan frekuensi ejakulasi pejantan berpengaruh terhadap konsentrasi spermatozoa.

Nilai $\mathrm{pH}$ yang didapatkan dalam penelitian ini sebesar 6,2-6,4 dengan rataan sebesar 6,3 \pm 0,07. Menurut Prasetyo (2019) rataan $\mathrm{pH}$ semen segar sapi umur 1,5 tahun adalah $7,01 \pm 0,12$ dan $7,00 \pm 0,23$ pada umur 2 tahun sedangkan Ina \& Kaka (2020) dalam penelitiannya menyatakan bahwa semen sapi memiliki rataan $\mathrm{pH}$ sebesar $6,76 \pm 0,12$. Terdapatnya perbedaan nilai $\mathrm{pH}$ pada semen ternak sapi diduga diakibatkan oleh perbedaan cara mengoleksi semen saat penampungan semen. Hal ini sesuai dengan pernyataan Sundari, Tagama, \& Maidaswar (2013) bahwa adanya variasi nilai $\mathrm{pH}$ semen dipengaruhi oleh beberapa faktor, diantaranya akibat aktivitas spermatozoa dalam menguraikan fruktosa sehingga $\mathrm{pH}$ menjadi menurun, adanya kontaminasi dengan mikroorganisme sehingga $\mathrm{pH}$ menjadi naik dan adanya perbedaan cara mengoleksi semen. Menurut Wahyuningsih, Saleh, \& Sugiyatno (2013) menjelaskan bahwa syarat $\mathrm{pH}$ semen untuk bisa diproses lebih lanjut bila memiliki $\mathrm{pH}$ antara 6,28-7,00. pH juga dapat mempengaruhi daya tahan spermatozoa akibat proses metabolisme sel spermatozoa. Bau semen yang diperoleh dalam penelitian ini adalah bau yang khas dari ternak sapi.

Hasil evaluasi secara mikroskopis diperoleh motilitas spermatozoa sapi SO ada pada kisaran normal sebesar 80-90 \% dengan rataan motilitas yakni $85,00 \pm 3,53$. Hasil yang didapatkan lebih tinggi jika dibandingkan dengan hasil penelitian Ina \& Kaka (2020) bahwa rataan motilitas semen segar sapi adalah 78,75 $\pm 3,93$, juga lebih tinggi jika dibandingkan dengan pendapat Pubiandara, Suharyanti, \& Hartono (2016) bahwa motilitas spermatozoa pada sapi sebesar $75 \%$. Adanya perbedaan motilitas spermatozoa pada ternak sapi di duga dipengaruhi oleh perbedaan umur ternak yang digunakan sebagai materi penelitian. Hal ini sesuai dengan penyataan Azzahra, Setiatin, \& Samsudewa (2016) bahwa perbedaan umur ternak sapi mempengaruhi motilitas spermatozoa karena perbedaan umur dipengaruhi oleh energi untuk daya gerak daya hidup spermatozoa dan hormon testoteron. Berdasarkan hasil evaluasi mikroskopis diperoleh semen sapi SO menunjukkan gerakkan massa adalah +++ yang berarti kualitas semen baik karena bentuk gelombang tebal seperti awan hitam pekat, aktif dan cepat bergerak. Hal ini sesuai yang disampaikan oleh Ina \& Kaka (2020) dalam penelitiannya bahwa gerakan massa semen sapi adalah +++ .

Konsentrasi spermatozoa sapi SO yang diperoleh sebesar 700-1950 juta/ml dengan nilai rataan sebesar $1276,00 \pm 487,37 \times 10^{6} / \mathrm{ml}$. Hasil penelitian ini tergolong tinggi dibandingkan hasil penelitian Yekti et al. (2018) yaitu rataan konsentrasi spermatozoa sapi mencapai $1210 \pm 160,87 \mathrm{juta} / \mathrm{ml}$ dan masih lebih rendah dibandingkan hasil penelitian Pubiandara et al. (2016) yakni rataan konsentrasi semen segar sapi adalah $2124 \times 10^{6} / \mathrm{ml}$. Terdapatnya perbedaan konsentrasi semen pada ternak sapi diduga dipengaruhi oleh ukuran testis yang berbeda pada masing-masing ternak sapi. Hal ini sesuai dengan pendapat Saputra et al. (2017) bahwa ukuran skrotum yang besar mengandung hormone testoteron yang berperan penting dalam merangsang spermatogenesis sehingga konsentrasi semen menjadi lebih tinggi. Selain itu perbedaan konsentrasi semen juga dipegaruhi oleh tingkat libido ternak sapi saat penampungan, saat libibo tinggi maka konsentasi semen yang dihasilkan juga akan tinggi. Hal ini sesuai dengan pendapat Saputra et al. (2017) bahwa perbedaan konsentasi semen dipengaruhi oleh tingkat libido pada masing-masing bangsa ternak sapi. Selanjutnya disampaikan oleh Saputra et al. (2017) bahwa penyebab tinggi 
rendahnya konsentrasi semen pada seekor pejantan dipengaruhi oleh tinggi rendahnya libido ternak sapi saat dilakukan penampungan semen.

Viabilitas semen segar yang dihasilkan dalam penelitian ini sebesar $71-97,49 \%$ dengan nilai rataan viabilitas yang diperoleh adalah 90,05 $\pm 10,98$. Hasil ini lebih tinggi jika dibandingkan dengan hasil penelitian Ina \& Kaka (2020) yakni rataan viabilitas semen segar sapi sebesar $78,95 \pm 3,31$, Sulistyowati et al. (2018) bahwa rataan viabilitas semen segar sapi yang didapatkan adalah 73,70 $\pm 9,39$ dan Pubiandara et al. (2016) bahwa rataan viabilitas semen segar sapi adalah 86,5 \%. Adanya perbedaan viabilitas spermatozoa pada ternak sapi di duga dipengaruhi oleh perbedaan umur ternak yang digunakan sebagai materi penelitian. Hal ini sesuai dengan penyataan Azzahra et al. (2016) bahwa perbedaan umur ternak sapi mempengaruhi motilitas spermatozoa karena perbedaan umur dipengaruhi oleh energi untuk daya gerak daya hidup spermatozoa dan hormon testoteron.

Abnormalitas semen segar yang dihasilkan sebesar 3,89-8,54 \% dengan rataan abnormalitas adalah $6,15 \pm 1,81$. Hasil penelititian ini lebih rendah dibandingkan penelitian Sulistyowati et al. (2018) bahwa rataan abnormalitas yang

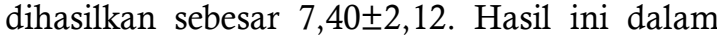
kategori baik dan memenuhi syarat sesuai pendapat Garner \& Hafez (2016) bahwa tingkat abnormalitas spermatozoa tidak boleh melebihi $20 \%$.

\subsection{Kualitas Semen Sapi So dalam Perlakuan}

Tabel 2. Rataan motilitas semen segar sapi SO

\begin{tabular}{lcccc}
\hline \multirow{2}{*}{ Pengamatan hari ke - } & \multicolumn{4}{c}{ Perlakuan } \\
\cline { 2 - 5 } & P0 & P1 & P2 & P3 \\
\hline 0 & $74,00 \pm 4,18$ & $75,00 \pm 5,00$ & $77,00 \pm 2,73$ & $76,00 \pm 4,18$ \\
1 & $53,00 \pm 29,91$ & $65,00 \pm 10,00$ & $65,00 \pm 7,07$ & $64,00 \pm 9,61$ \\
2 & $2,00 \pm 4,47$ & $29,00 \pm 35,42$ & $14,00 \pm 20,73$ & $29,00 \pm 24,84$ \\
\hline
\end{tabular}

Sumber: Data primer yang telah diolah.

Pengaruh suplementasi SKD selama penyimpanan menunjukkan bahwa penggunaan SKD pada penyimpanan semen tidak mampu memberikan efek yang berbeda terhadap motilitas spermatozoa walaupun dilihat dari nilai rataan menunjukkan bahwa $\mathrm{P} 1, \mathrm{P} 2$ dan $\mathrm{P} 3$ lebih tinggi dari PO yang tidak menggunakan SKD. $\mathrm{Hal}$ ini menunjukkan bahwa lesitin dalam SKD belum mampu melindungi spermatozoa dari kejutan dingin selama proses preservasi, serta proses metabolisme yang terus terjadi menyebabkan sumber energi berupa glukosa dalam BTS yang cepat habis menyebabkan daya

\section{Motilitas Spermatozoa dalam Perlakuan}

Motilitas spermatozoa semen sapi SO yang diencerkan dengan BTS yang dimodifikasi dengan SKD disajikan pada Tabel 2. Berdasarkan rataan motilitas pada Tabel 2 menunjukkan bahwa penambahan pengencer BTS dengan SKD ke dalam semen ternak sapi SO di antara empat perlakuan tidak menunjukkan pengaruh $(\mathrm{P}>0,05)$ nyata terhadap motilitas spermatozoa sapi selama penyimpanan sampai hari ke-2. Dari hasil tersebut menunjukkan bahwa bahan pengencer BTS yang disuplementasi SKD hanya mampu bertahan selama 24 jam penyimpanan. Hal ini diduga diakibatkan karena bahan pengencer BTS merupakan bahan pengencer short-term yang memiliki daya penyimpanan dalam jangka pendek. Sebagai bahan pengencer short-term maka kandungan sumber energi dalam bahan pengencer cepat habis sehingga akibat dari kehabisan energi menyebabkan terhentinya pergerakan spermatozoa karena energi berperan penting untuk kehidupan dan pergerakan spermatozoa. Hal ini sesuai dengan pendapat MataHine et al. (2014) bahwa habisnya ATP sebagai sumber energi menyebabkan terhentinya pergerakan spermatozoa. Hal serupa juga disampaikan Rizal \& Riyadhi (2016), di dalam bahan pengencer semen substrat energi harus selalu tersedia selama penyimpanan karena hal itu akan menjamin berlangsungnya proses glikolisis untuk menghasilkan energi berupa ATP sehingga pergerakan (motilitas) spermatozoa dapat dipertahankan. simpan semen hanya mampu bertahan selama 24 jam penyimpanan. Hal ini berlainan dengan pendapat Coester, Sulaiman, \& Rizal (2019) bahwa lesitin yang terkandung dalam sari kedelai dapat melindungi membran plasma sel spermatozoa selama penyimpanan pada suhu rendah.

Pada saat preservasi spermatozoa harus bisa terlindungi dari cold shock karena jika tidak terlindungi menyebabkan terjadinya kerusakan membran plasma sel spermatozoa sehingga motilitas spermatozoa menjadi menurun. Hal ini sesuai dengan $\mathrm{Hal}$ ini sesuai dengan pendapat 
Dapawole (2014) menyatakan bahwa penurunan motilitas maupun viabilitas spermatozoa juga dapat terjadi sebagai akibat penurunan suhu yang rendah yang menyebabkan terjadinya perubahan phospholipid sehingga menyebabkan terjadinya kerusakan membran plasma secara permanen akibat cold shock. Hal serupa disampaikan MataHine et al. (2014), keutuhan membran sel dapat terganggu akibat suhu dingin. Rusaknya membran plasma mengakibatkan terlepasnya enzim aspartat aminotransferase (AspAT) dari dalam mitokondria yang memproduksi ATP dan masuk ke dalam seminal plasma sehingga akibat dari terlepasnya enzim AspAT tersebut menyebabkan terganggunya produksi ATP dan mengganggu motilitas spermatozoa (Arifiantini \& Purwantara, 2010).

Penggunaan bahan pengencer BTS yang disuplementasi dengan SKD pada semen sapi SO dapat digunakan sebagai pengencer semen sapi SO karena komposisi bahan pengencer yang lebih lengkap yaitu pengencer BTS berperan sebagai sumber energi karena terdapat glukosa, EDTA yang berfungsi dalam mengatur kadar $\mathrm{Ca}$ dalam larutan, antibiotik yang berfungsi untuk menekan pertumbuhan bakteri, unsur-unsur seperti natrium sitrat, natrium bicarbonat berfungsi sebagai penyangga serta potasium klorida yang berfungsi untuk menghentikan aktivitas spermatozoa. Sedangkan SKD sebagai sumber lesitin yang dapat melindungi spermatozoa dari cold shock. Selain itu, penambahan SKD dalam BTS juga bisa mengurangi terhadap penggunaan BTS karena harga BTS terkesan lebih mahal dengan demikian biaya pembuatan bahan pengencer dapat dikurangi lewat penambahan suplementasi SKD karena syarat bahan pengencer adalah mudah didapat, aman bagi spermatozoa maupun saluran reproduksi ternak dan harga harus murah.

Syarat persentase semen untuk pelaksanaan IB berdasarkan standar SNI adalah spermatozoa motil minimal $40 \%$. Berdasarkan hasil penelitian ini pelaksanaan IB sebaiknya dilakukan pada waktu yang tidak lebih dari 24 jam penyimpanan.

\section{Viabilitas Spermatozoa dalam Perlakuan}

Viabilitas spermatozoa semen sapi SO yang diencerkan dengan BTS yang dimodifikasi dengan SKD disajikan pada Tabel 3. Berdasarkan rataan viabilitas pada Tabel 3 menunjukkan bahwa penambahan pengencer BTS dengan SKD ke dalam semen ternak sapi SO di antara empat perlakuan tidak menunjukkan pengaruh $(\mathrm{P}>0,05)$ nyata terhadap viabilitas spermatozoa sapi selama penyimpanan sampai hari ke-2. Dari hasil tersebut menunjukkan bahwa bahan pengencer BTS yang disuplementasi SKD hanya mampu bertahan selama 24 jam penyimpanan. Hal ini diduga diakibatkan karena bahan pengencer BTS merupakan bahan pengencer short-term yang memiliki daya penyimpanan dalam jangka pendek. Sebagai bahan pengencer short-term maka kandungan sumber energi dalam bahan pengencer cepat habis sehingga akibat dari kehabisan energi menyebabkan kematian spermatozoa karena energi berperan penting untuk kehidupan dan pergerakan spermatozoa. Hal ini sesuai dengan pendapat Blegur, Nalley, \& Hine (2020) bahwa nutrisi akan digunakan oleh spermatozoa untuk dijadikan energi sehingga apabila kebutuhan nutrisi spermatozoa berkurang maka akan mengakibatkan viabilitas spermatozoa menjadi menurun.

Tabel 3. Rataan viabilitas semen segar sapi SO

\begin{tabular}{lcccc}
\hline \multirow{2}{*}{ Pengamatan hari ke - } & \multicolumn{4}{c}{ Perlakuan } \\
\cline { 2 - 5 } & P0 & P1 & P2 & P3 \\
\hline 0 & $73,60 \pm 6,22$ & $79,00 \pm 4,94$ & $78,80 \pm 7,01$ & $79,60 \pm 6,38$ \\
1 & $54,00 \pm 31,61$ & $65,20 \pm 15,59$ & $74,40 \pm 9,28$ & $73,80 \pm 10,40$ \\
2 & $6,80 \pm 15,20$ & $29,60 \pm 32,47$ & $17,40 \pm 19,79$ & $32,60 \pm 20,08$ \\
\hline
\end{tabular}

Sumber: Data primer yang telah diolah.

Selama penyimpanan suplementasi SKD menunjukkan bahwa tidak terdapat pengaruh yang berbeda terhadap viabilitas semen. Hal ini menunjukkan bahwa lesitin dalam SKD belum mampu melindungi spermatozoa dari kejutan dingin selama proses preservasi dan proses metabolisme yang terus terjadi menyebabkan sumber energi berupa glukosa dalam BTS yang cepat habis menyebabkan daya simpan semen hanya mampu bertahan selama 24 jam penyimpanan. hasil penelitian ini berbeda dengan pendapat Coester et al. (2019) yang mengemukakan bahwa lesitin yang terkandung dalam sari kedelai mampu melindungi membran plasma sel spermatozoa selama penyimpanan pada suhu rendah.

Pada saat preservasi spermatozoa harus bisa terlindungi dari cold shock karena jika tidak terlindungi menyebabkan terjadinya kerusakan membran plasma sel spermatozoa sehingga viabilitas spermatozoa menjadi menurun. Hal ini sesuai dengan pendapat Dapawole (2014) 
menyatakan bahwa penurunan motilitas maupun viabilitas spermatozoa juga dapat terjadi sebagai akibat penurunan suhu yang rendah yang menyebabkan terjadinya perubahan phospholipid sehingga menyebabkan terjadinya kerusakan membran plasma secara permanen akibat cold shock. Pubiandara et al. (2016) juga menyatakan bahwa kejutan dingin berpengaruh pada perubahan fosfolipida yang menyebabkan kerusakan membran plasma sehingga ion-ion seperti kalsium bebas masuk ke dalam sel. Rusaknya membran plasma mengakibatkan terlepasnya enzim aspartat aminotransferase (AspAT) dari dalam mitokondria yang memproduksi ATP dan masuk ke dalam seminal plasma sehingga akibat dari terlepasnya enzim AspAT tersebut menyebabkan terganggunya produksi ATP dan mengganggu motilitas spermatozoa (Arifiantini \& Purwantara, 2010). Selain itu lama penyimpanan semen juga mempengaruhi kualitas spermatozoa, semakin lama semen disimpan setelah diencerkan maka akan semakin rendah daya hidup spermatozoa dan semakin pendek jangka simpan atau semakin cepat semen digunakan akan semakin tinggi daya hidup spermatozoa. Hal ini disebabkan meningkatnya spermatozoa yang rusak dan mati akibat kekurangan energi selama proses penyimpanan serta terjadinya perubahan suhu penyimpanan.

Penggunaan bahan pengencer BTS yang disuplementasi dengan SKD pada semen sapi SO dapat digunakan sebagai pengencer semen sapi SO karena komposisi bahan pengencer yang lebih lengkap yaitu pengencer BTS berperan sebagai sumber energi karena terdapat glukosa, EDTA yang berfungsi dalam mengatur kadar $\mathrm{Ca}$ dalam larutan, antibiotik yang berfungsi untuk menekan pertumbuhan bakteri, unsur-unsur seperti natrium sitrat, natrium bicarbonat berfungsi sebagai penyangga serta potasium klorida yang berfungsi untuk menghentikan aktivitas spermatozoa. Sedangkan SKD sebagai sumber lesitin yang dapat melindungi spermatozoa dari cold shock. Selain itu, penambahan SKD dalam BTS juga bisa mengurangi terhadap penggunaan BTS karena harga BTS terkesan lebih mahal dengan demikian biaya pembuatan bahan pengencer dapat dikurangi lewat penambahan suplementasi SKD karena syarat bahan pengencer adalah mudah didapat, aman bagi spermatozoa maupun saluran reproduksi ternak dan harga harus murah.

Persentasi viabilitas semen untuk pelaksanaan IB pada ternak sapi minimal $40 \%$ harus segera digunakan. Berdasarkan hasil penelitian ini maka pelaksanaan IB sebaiknya dilakukan pada waktu yang tidak lebih dari 24 jam penyimpanan.

\section{Kesimpulan}

Karakteristik spermatozoa sapi Sumba Ongole selama penelitian dinyatakan berkategori normal yakni warna semen putih krem, volume semen 3,6 ml, konsistensi sedang, $\mathrm{pH}$ 6,3, bau yang khas, motilitas semen segar $85 \%$, gerakan massa +++ , konsentrasi 1276 juta/ml, viabilitas semen segar 90,05 \% dan abnormalitas $6,15 \%$. Sedangkan pengencer BTS dengan penambahan SKD tidak mampu mempertahankan motilitas dan viabilitas spermatozoa. Untuk keperluan IB dari keempat perlakuan masih layak untuk dilakukan dengan tidak lebih dari 24 jam penyimpanan.

\section{Daftar Pustaka}

Adhyatma, M., Isnaini, N., \& Nuryadi. (2013). Pengaruh bobot badan terhadap kualitas dan kuantitas semen sapi Simmental. Jurnal Ternak Tropika, 14(2), 53-62.

Arifiantini, I., Nally, W. M. M., Susnawati, T., \& Rochmiati, E. (2014). Individual variation on the sperm freezing capability of Etawah grade. Proceedings of The 2nd Asian-Australasian Dairy Goat Conference, 127-130.

Arifiantini, R. I. (2012). Teknik Koleksi dan Evaluasi Semen pada Hewan (L. T. Yusuf, Ed.). Bogor: IPB Press.

Arifiantini, R. I., \& Purwantara, B. (2010). Motility and viability of Friesian Holstein spermatozoa in three different extender stored at $5^{\circ} \mathrm{C}$. Journal of the Indonesian Tropical Animal Agriculture, 35(4), 222-226. https://doi.org/10.14710/jitaa.35.4.222226

Azzahra, F. Y., Setiatin, E. T., \& Samsudewa, D. (2016). Evaluasi motilitas dan persentase hidup semen segar sapi PO Kebumen pejantan muda. Jurnal Sain Peternakan Indonesia, 11(2), 99-107. https://doi.org /10.31186/jspi.id.11.2.99-107

Bebas, W., Buyona, G. L., \& Budiasa, M. K. (2016). Penambahan vitamin E pada pengencer BTS $\AA$ terhadap daya hidup dan motilitas spermatozoa babi Landrace pada penyimpanan $15{ }^{\circ} \mathrm{C}$. Buletin Veteriner Udayana, 8(1), 1-7.

Blegur, J., Nalley, W. M., \& Hine, T. M. (2020). Pengaruh penambahan virgin coconut oil 
dalam pengencer tris kuning telur terhadap kualitas spermatozoa sapi Bali selama preservasi. Jurnal Nukleus Peternakan, 7(2), 130-138.

BPS Kabupaten Sumba Timur. (2019). Sumba Timur dalam Angka 2019. Retrieved April 10, 2021, from https://sumbatimurkab. bps.go.id/

Coester, J. S., Sulaiman, A., \& Rizal, M. (2019). Daya hidup spermatozoa sapi Limousin yang dipreservasi dengan pengencer tris dan berbagai konsentrasi sari kedelai. Jurnal Ilmu Dan Teknologi Peternakan Tropis, 6(2), 175-180. https://doi.org/10.33772/ jitro.v6i2.6023

Dapawole, R. R. (2014). Preservasi dan kriopreservasi semen babi dalam pengencer BTS dan MIII yang disuplementasi dengan dan tanpa trehalosa. Sekolah Pascasarjana, Institute Pertanian Bogor.

Dewi, A. S., Ondho, Y. S., \& Kurnianto, E. (2012). Kualitas semen berdasarkan umur pada sapi jantan Jawa. Animal Agriculture Journal, 1(2), 126-133.

Direktorat Budidaya Ternak Ruminansia. (2010). Pedoman Teknis Alat Mesin dan ULIB Budidaya Ternak Ruminansia. Jakarta Selatan: Kementrian Pertanian, Direktorat Jenderal Peternakan.

El-Keraby, F. E., Osman, K. T., Ganah, H. B., \& El-Siefy, E. M. (2010). Soymilk-based extender for cryopreservation of bovine semen. Journal of Animal and Poultry Production, 1(2), 61-69. https://doi.org/10. 21608/jappmu.2010.86093

Feradis. (2010). Bioteknologi Reproduksi pada Ternak. Bandung: Alfabveta.

Fuadi, Y., \& Sugiarto. (2019). Menuju swasembada daging sapi. Seminar Nasional Official Statistics: Pengembangan Official StatisticsdDalam Mendukung Implementasi Suistainable Development Goals, 152-160. Jakarta: Politekni Statistika STIS.

Garner, D. L., \& Hafez, E. S. E. (2016). Spermatozoa and Seminal Plasma. In B. Hafez \& E. S. E. Hafez (Eds.), Reproduction in Farm Animals (pp. 96-109). Wiley Online Library. https://doi.org/10.1002/9781119 265306.ch7

Hartanti, D., Setiati, E. T., \& Sutopo. (2012). Perbandingan penggunaan pengencer semen sitrat kuning telur dan tris kuning telur terhadap persentase daya hidup spermatozoa sapi Jawa Brebes. Animal Agriculture Journal, 1(1), 33-42.

Ina, A. T., \& Kaka, A. (2020). Preservation of spermatozoa Sumba Ongole bulls using citrate yolk diluent with the addition of palmyra palm juice. Jurnal Ternak, 11(2), 86-90. https://doi.org/10.30736/jt.v11i2. 83

Ismaya. (2014). Bioteknologi Inseminasi Buatan pada Sapi dan Kerbau. Yogyakarta: Gadjah Mada University Press.

Khairi, F. (2017). Evaluasi produksi dan kualitas semen sapi Simmental terhadap tingkat bobot badan berbeda. Jurnal Peternakan, 13(2), 54-58.

Kusumawati, E. D., \& Leondro, H. (2014). Kualitas semen segar sapi pejantan pada penyimpanan dan lama simpan yang berbeda. In D. T. Kartono, S. P. K. Surata, \& I. K. Arnawa (Eds.), SEMNAS 2014 Hasil-Hasil Penelitian Sebagai Aktualisasi Pelaksanaan Tri Dharma Perguruan Tinggi (pp. 433-439). Denpasar: UNMAS Press.

MataHine, T., Burhanuddin, \& Marawali, A. (2014). Efektivitas air buah lontar dalam mempertahankan motilitas, viabilitas dan daya tahan hidup spermatozoa sapi Bali. Jurnal Veteriner, 15(2), 263-273.

Menteri Pertanian Republik Indonesia. (2014). Keputusan Menteri Pertanian Republik Indonesia Nomor 427/Kpts/SR.120/3/2014 Tentang Penetapan Rumpun Sapi Sumba Ongol. Menteri Pertanian Republik Indonesia.

Prasetyo, H. (2019). Kualitas makroskopis semen segar pejantan sapi Peranakan Ongole Kebumen pada umur yang berbeda. Fakultas Peternakan dan Pertanian, Universitas Diponegoro.

Pubiandara, S., Suharyanti, S., \& Hartono, M. (2016). Pengaruh penambahan dosis rafinosa dalam pengencer sitrat kuning telur terhadap motilitas, persentase hidup, dan abnormalitas spermatozoa sapi Ongole. Jurnal Ilmiah Peternakan Terpadu, 4(4), 292-299. https://doi.org/10.23960/ jipt.v4i4.1395

Purwoistri, R. F., Susilawati, T., \& Rahayu, S. (2013). Membran spermatozoa hasil seksing gradien albumin berpengencer andromed dan cauda epididymal plasma- 2 ditambahkan kuning telur. Jurnal Veteriner, 
14(3), 371-378.

Rahayu, W., Pramana, W. M. A., \& Ciptadi, G. (2014). Kualitas semen segar kambing Boer pada temperatur penyimpanan $4{ }^{\circ} \mathrm{C}$ dengan menggunakan pengencer sitrat dan suplementasi susu kedelai bubuk. Biotropika: Journal of Tropical Biology, 2(1), $55-60$.

Rizal, M., \& Riyadhi, M. (2016). Fertilitas semen kerbau rawa (Bubalus bubalis carabanensis) yang diencerkan dengan pengencer nira aren. Jurnal Veteriner, 17(3), 457-467. https://doi.org/10.19087/jveteriner.2016. 17.3.457

Saputra, D. J., Ihsan, M. N., \& Isnaini, N. (2017). Korelasi antara lingkar skrotum dengan volume semen, konsentrasi dan motilitas spermatozoa pejantan sapi Bali. Jurnal Ternak Tropika, 18(2), 59-68. https://doi.org/10.21776/ub.jtapro.2017. 018.02.9

Sholikah, N., Isnaini, N., Puspita Anugra Yekti, A., \& Susilawati, T. (2016). Pengaruh penggantian bovine serum albumin (BSA) dengan putih telur pada pengencer CEP-2 terhadap kualitas semen sapi Peranakan Ongole pada suhu penyimpanan $3-5^{\circ} \mathrm{C}$. Jurnal Ilmu-Ilmu Peternakan, 26(1), 7-15. https://doi.org/10.21776/ub.jiip.2016.02 6.01 .2

Steel, R. G. D., \& Torrie, J. H. (1991). Prinsib dan Prosedur Satistika: Suatu Pendekatan Biometrik (Bambang Sumantri, Ed.). Jakarta: Gramedia Pustaka Utama.

Sulistyowati, D., Faris, M. A., Yekti, A. P. A., Wahjuningsih, S., \& Susilawati, T. (2018). Kualitas semen cair sapi Peranakan Ongole pada pengencer tris aminomethan kuning telur tanpa raffinosa yang disimpan pada media yang berbeda suhu. Jurnal Ternak Tropika, 19(1), 38-45. https://doi.org/10. 21776/ub.jtapro.2018.019.01.6

Sundari, T. W., Tagama, T. R., \& Maidaswar. (2013). Korelasi kadar pH semen segar dengan kualitas semen sapi Limousin di Balai Inseminasi Buatan Lembang. Jurnal Ilmiah Petenakan, 1(3), 1043-1049.

Susilawati, T. (2013). Pedoman Inseminasi Buatan pada Ternak. Malang: Universitas Brawijaya Press.

Wahyuningsih, A., Saleh, D. M., \& Sugiyatno. (2013). Pengaruh umur pejantan dan frekuensi penampungan terhadap volume dan motilitas semen segar sapi Simmental di Balai Inseminasi Buatan Lembang. Jurnal Ilmiah Peternakan, 1(3), 947-953.

Yekti, A. P. A., Tatulus, W. S. S., Ratnawati, D., Affandhy, L., Kuswati, Huda, A. N., \& Susilawati, T. (2018). Kualitas dan kapasitasi spermatozoa sapi Bali, Madura, dan Peranakan Ongole. Jurnal Ilmu Dan Teknologi Peternakan Tropis, 5(2), 34-41. https://doi.org/10.33772/jitro.v5i2.4739 